\title{
PENGARUH AKTIVITAS PEMASARAN, KINERJA KEUANGAN, DAN ASET TIDAK BERWUJUD TERHADAP NILAI PERUSAHAAN
}

\author{
Muhammad Teguh Akbar Kombih \\ teguhakbarkombih@gmail.com \\ Novrys Suhardianto \\ Fakultas Ekonomi dan Bisnis, Universitas Airlangga
}

\begin{abstract}
Consumer goods industry focuses on consumers' daily needs, which make the competition between companies in this industry become higher. Therefore, company has to improve by increasing their brand equity through doing marketing effectively. The purpose of this research is to analyze the influence of marketing activity on firm value, as an addition of fundamental accounting measures. This research hypothesized that marketing activity, profitability, liquidity, solvability, and intangible assets influence firm value that measured by Tobins'q. The sample used is consumer goods companies listed in Indonesia stock exchange during the period of 2012-2014. The result shows that the increase of marketing activity, profitability, and solvability improve firm value. On the other hand, liquidity has negative relationship to firm value. However, intangible assets do not contribute to improve firm value in several models tested. The results imply that marketing activity provides benefits in creating value of firm besides accounting performance though it is expensed as incurred.
\end{abstract}

Key words: marketing activity, intangible assets, accounting fundamentals, firm value, competitive industry.

\begin{abstract}
ABSTRAK
Industri barang konsumen berfokus pada kebutuhan sehari-hari konsumen, yang menyebabkan tingkat kompetisi antar perusahaan dalam industri ini menjadi lebih tinggi. Oleh sebab itu, perusahaan harus meningkatkan modal merek melalui kegiatan pemasaran secara efektif. Penelitian ini bertujuan untuk menganalisis pengaruh aktivitas pemasaran terhadap nilai perusahaan sebagai tambahan dari ukuran akuntansi fundamental. Penelitian ini berhipotesis bahwa aktivitas pemasaran, profitabilitas, likuiditas, solvabilitas, dan aset tidak berwujud menentukan nilai perusahaan yang diukur dengan Tobins' q. Sampel yang digunakan adalah perusahaan barang konsumen diperoleh dari bursa efek Indonesia selama periode 2012-2014. Penelitian ini menggunakan analisis regresi dan analisis data panel untuk mengevaluasi beberapa model. Hasil penelitian menunjukkan bahwa aktivitas pemasaran, profitabilitas, dan solvabilitas akan meningkatkan nilai perusahaan. Di sisi lain, likuiditas berpengaruh negatif terhadap nilai perusahaan, namun demikian, aset tidak berwujud tidak berkontribusi dalam membentuk nilai perusahaan dalam beberapa model yang diuji. Hasil penelitian mengimplikasikan bahwa aktivitas pemasaran memiliki manfaat ekonomi dalam menciptakan nilai perusahaan kendati selalu dibebankan pada saat terjadi.
\end{abstract}

Kata kunci: aktivitas pemasaran, aset tidak berwujud, fundamental akuntansi, nilai perusahaan, industri kompetitif

\section{PENDAHULUAN}

Tidak bisa dipungkiri lagi perkembangan dunia usaha di Indonesia yang semakin kompetitif menuntut setiap perusahaan untuk dapat mengolah dan melaksanakan manajemen perusahaan menjadi lebih profesional. Bertambahnya pesaing di setiap saat, baik pesaing yang berorientasi lokal maupun pesaing yang berorientasi internasional mengharuskan setiap perusahaan menampilkan yang terbaik, baik dalam segi kinerja perusahaan juga harus ditunjang dengan strategi yang matang dalam segala segi. Berbagai macam strategi 
diimplementasikan oleh setiap perusahaan untuk menanggapi kondisi ini, dan aktivitas pemasaran adalah salah satunya. Tujuan utama dari aktivitas pemasaran adalah untuk meningkatkan kinerja keuangan jangka panjang perusahaan disamping juga menciptakan keunggulan bersaing secara berkelanjutan (Kanagal, 2009). Hal ini dilakukan agar perusahaan dapat mempertahankan aktivitas serta eksistensi perusahaan. Beriklan merupakan salah satu aktivitas pemasaran yang paling berpengaruh terhadap kinerja perusahaan sehingga membuat para manajer cenderung akan mengalokasikan sumber daya yang dimiliki dalam jumlah besar untuk beriklan agar dapat meningkatkan penjualan dan akhirnya akan berdampak pada peningkatan nilai perusahaan (Kim dan Joo, 2013).

Sektor barang konsumsi merupakan sektor yang paling gencar melaksanakan promosi produk atau jasanya karena tingkat persaingannya yang ketat. Hasil survei dari Nielsen (2015) menunjukkan bahwa sektor ini mendominasi belanja iklan terbesar untuk periode 2014 dan semester awal 2015.

Di samping itu, menurut Kementerian Perindustrian Indonesia (2014), dari 10 emiten terbesar indeks manufaktur yang menjadi penggerak indek (index mover), sebanyak lima dari enam emiten terbesar yang mencatat kenaikan merupakan emiten indeks konsumen sehingga sektor konsumen merupakan kontributor terbesar secara sektoral. Saham-saham dari emiten ini menjadi pilihan karena menawarkan potensi kenaikan. Perusahaan-perusahaan tersebut adalah produsen kebutuhan mendasar konsumen seperti makanan, minuman, obat, daging, dan produk toiletries yang menjadi kebutuhan sehari-hari masyarakat.

Berbagai strategi diimplementasikan oleh manajemen untuk menanggapi persaingan di sektor barang konsumsi, dan aktivitas pemasaran adalah salah satunya. Tujuan utama dari aktivitas pemasaran adalah untuk meningkatkan kinerja jangka panjang perusahaan disamping juga menciptakan keunggulan bersaing secara ber- kelanjutan (Kanagal, 2009). Kim dan Joo (2013) mengatakan bahwa beriklan merupakan salah satu aktivitas pemasaran dan berpengaruh terhadap kinerja perusahaan. Srinivasan dan Hanssens (2009) menyatakan bahwa pemasaran berkontribusi dalam penciptaan nilai perusahaan kendati akuntansi tidak mampu mengukur manfaat ekonominya. Gurun dan Butler (2012) menjelaskan bahwa iklan mempengaruhi media masa dan harapan investor terhadap nilai perusahaan.

Peran aset tidak berwujud di sektor barang konsumsi juga sangat penting. Kekuatan merek produk atau paten formula produk menghasilkan manfaat ekonomi bagi perusahaan sektor barang konsumsi. Soraya dan Syafruddin (2013) maupun Chen et al. (2005) menyatakan bahwa aset tidak berwujud memiliki kontribusi signifikan dalam penciptaan nilai perusahaan. Srivastava (2014) menjelaskan bahwa intensitas aset tidak berwujud meningkat dekade belakangan ini karena bisnis semakin dinamis dan lebih banyak berbasis pada pengetahuan. Peran aset tidak berwujud sebagai cerminan kekayaan intelektual perusahaan semakin tinggi di era ekonomi yang berbasis pengetahuan (Teece, 1998).

Kendati demikian, kinerja keuangan perusahaan tetap menjadi pemicu utama persepsi investor terhadap nilai perusahaan. Harga saham yang menjadi salah satu komponen dalam perhitungan nilai perusahaan akan bergerak linier dengan pergerakan kinerja perusahaan. Putra dan Herawati (2013) menyatakan bahwa secara simultan profitabilitas, struktur modal, ukuran perusahaan, dan likuiditas berpengaruh terhadap nilai perusahaan. Rasio keuangan seperti ROA, leverage, maupun current ratio selalu digunakan sebagai variabel kontrol penelitian terdahulu karena kemampuan rasio tersebut dalam memprediksi nilai perusahaan (Ammann et al., 2011; Jo dan Harjoto, 2011; Nini et al., 2012). Oleh sebab itu, peran kinerja keuangan dalam penciptaan nilai perusahaan tidak bisa dinihilkan. 
Penelitian ini bertujuan membuktikan secara empiris kemampuan aktivitas pemasaran, aset tidak berwujud, dan kinerja keuangan dalam menciptakan nilai perusahaan sektor biaya konsumsi. Tekanan persaingan di sektor barang konsumsi direspon oleh perusahaan dengan aktivitas pemasaran yang gencar dan pengembangan produk untuk penciptaan nilai perusahaan kendati perusahaan harus tetap menjaga kinerja keuangannya. Hal ini melatar belakangi penelitian ini untuk mengungkap peran aktivitas pemasaran, aset tidak berwujud, dan kinerja keuangan dalam menciptakan nilai perusahaan.

Penelitian ini memberi kontribusi terhadap beberapa aspek. Manfaat teoritis dari penelitian ini adalah untuk menguji teori sinyal (signalling theory) terkait dengan faktor penentu nilai perusahaan. Hasil penelitian ini menunjukkan bahwa teori ini masih relevan, diindikasikan oleh kemampuan informasi akuntansi dalam memberikan sinyal bagi investor untuk memprediksi nilai perusahaan. Manfaat praktis dari penelitian ini adalah memberikan informasi untuk investor dan manajemen bahwa profitabilitas, likuiditas, solvabilitas, dan aktivitas pemasaran bisa digunakan dalam memprediksi nilai perusahaan. Hasil penelitian ini menunjukkan bahwa aset tidak berwujud kehilangan relevansinya sehingga tidak bisa digunakan untuk memprediksi nilai perusahaan. Dengan demikian, penelitian ini juga dapat dimanfaatkan oleh Dewan Standar Akuntansi Keuangan (DSAK) untuk dapat meninjau kembali PSAK 19 (Ikatan Akuntan Indonesia, 2016) agar informasi aset tidak berwujud relevan untuk pengambilan keputusan investasi bagi investor di semua sektor. Lebih dari itu, penelitian ini menunjukkan bahwa biaya pemasaran yang menurut perspektif akuntansi tidak memberi manfaat ekonomi justru dinilai oleh investor dalam menentukan ekspektasi nilai perusahaan.

\section{TINJAUAN TEORETIS} Teori Sinyal
Teori sinyal (signalling theory) menyatakan bahwa perusahaan secara sengaja memberikan sinyal kepada pasar, dengan demikian diharapkan pasar akan bereaksi dan memberi pengaruh terhadap harga saham perusahaan. Jika sinyal perusahaan menginformasikan kabar baik pada pasar maka diharapkan dapat meningkatkan harga saham, sebaliknya jika sinyal perusahaan menginformasikan kabar buruk maka harga saham perusahaan akan mengalami penurunan. Sinyal-sinyal tersebut dapat diberikan perusahaan lewat penyampaian laporan keuangan. Hal ini dapat mengurangi asimetri informasi yang terjadi antara manajemen selaku agen pelaksana dan investor selaku pemilik. Morris (1987) menyatakan bahwa teori sinyal ini relevan untuk menjelaskan masalah asimetri informasi antara perusahaan dengan para calon investor. Teori sinyal digunakan dalam penelitian ini untuk menghubungkan variabel dependen penelitian ini yang berasal dari respon investor dengan variabel independen yang berupa variabel-variabel akuntansi yang diasumsikan mengandung sinyal.

\section{Nilai Perusahaan}

Nilai perusahaan merupakan ekspektasi investor terhadap perusahaan, yang sering dikaitkan dengan harga saham. Harga saham yang tinggi membuat nilai perusahaan juga tinggi. Memaksimumkan nilai perusahaan dan kekayaan pemegang saham merupakan tujuan utama perusahaan menurut theory of the firm (Hermuningsih, 2013). Memaksimalkan nilai perusahaan sangat penting artinya bagi suatu perusahaan, karena secara otomatis juga memaksimalkan kemakmuran pemegang saham yang juga merupakan tujuan utama perusahaan. Nilai perusahaan yang tinggi akan membuat pasar percaya pada kinerja perusahaan saat ini dan juga prospek perusahaan di masa depan.

Nilai perusahaan umumnya diukur menggunakan Tobin's $Q$. Tobin's $Q$ memainkan peran penting dalam banyak penelitian 
keuangan. Didefinisikan sebagai rasio nilai pasar terhadap biaya perolehan aset perusahaan, Tobin's $Q$ telah digunakan untuk menjelaskan sejumlah fenomena perusahaan seperti perbedaan investasi dan keputusan diversifikasi, hubungan antara kepemilikan saham perusahaan dengan nilai perusahaan, dan kebijakan dividen serta kebijakan pendanaan (Chung dan Pruitt, 1994).

\section{Pengaruh Aktivitas Pemasaran Terhadap Nilai Perusahaan}

(Kotler dan Armstrong, 2014) mendefinisikan marketing sebagai suatu proses menciptakan nilai konsumen yang dimulai dari memahami kebutuhan pasar dan keinginan konsumen serta proses mengelola hubungan dengan konsumen. Hal ini akan meningkatkan nilai merek dan nilai perusahaan sebagai imbalan atas kepuasan dan inovasi yang terus diberikan perusahaan kepada konsumen (Serenia dan Hatane, 2015).

Beban pemasaran adalah sejumlah uang yang dikeluarkan perusahaan pada aktivitas pemasaran dan dapat dikatakan sebagai pertimbangan penting bagi semua bisnis karena pemasaran adalah fungsi bisnis utama yang dapat menarik pelanggan serta menciptakan keuntungan untuk perusahaan. Sangatlah penting bagi para pemilik usaha untuk memahami pentingnya beban pemasaran serta bagaimana mengelolanya agar dapat memberikan keuntungan bagi perusahaan secara berkesinambungan. Kegiatan pemasaran meliputi dari menentukan produk atau jasa yang diberikan, menentukan pelanggan yang menjadi target dan terakhir adalah bagaimana cara agar mereka tertarik dengan produk atau jasa yang ditawarkan. Saat ini kegiatan pemasaran menjadi komponen yang tidak terpisahkan dalam suatu organisasi. Setiap perusahaan harus terus dapat bertahan dengan mampu mempromosikan produk secara memadai. Konsumen mempertimbangkan tidak hanya bagaimana performa dari sebuah produk tapi juga ditentukan dari keseluruhan nilai dari produk. Kegiatan pemasaran itu sendiri dapat berupa iklan, promosi penjualan, hubungan masyarakat (sosialisasi), atau penjualan langsung. Efektifitas dalam pelaksanaan kegiatan pemasaran tersebut akan menjadi sinyal positif yang menandakan bahwa perusahaan siap untuk bersaing di pasar persaingan yang ketat.

Kim dan Joo (2013) menyatakan bahwa aktivitas pemasaran berpengaruh terhadap kinerja perusahaan sehingga membuat para manajer cenderung mengalokasikan sumber daya yang dimiliki dalam jumlah besar untuk beriklan agar dapat meningkatkan penjualan. Hal ini menandakan bahwa informasi tentang semakin besarnya beban pemasaran yang dikeluarkan perusahaan menjadi sinyal positif bagi investor. Pengeluaran program pemasaran mencerminkan perusahaan sedang memiliki produk unggulan yang dinilai akan mampu membawa perusahaan pada posisi unggul dari pada pesaing.

Irawan dan Hatane (2015) serta Ciawi dan Hatane (2015) menyatakan bahwa variabel aktivitas pemasaran berpengaruh positif terhadap nilai perusahaan karena investor pasar modal merespon positif usaha yang menjanjikan return lebih baik. Morgan (2012) menjelaskan bahwa salah satu faktor yang menyebabkan suatu perusahaan lebih unggul dari yang lain adalah strategi pemasaran. Chauvin dan Hirschey (1993) juga menemukan bahwa aktivitas periklanan yang merupakan bagian dari pemasaran memiliki pengaruh terhadap nilai perusahaan. Oleh sebab itu, penelitian ini mengajukan hipotesis:

$\mathrm{H}_{1}$ : Aktivitas Pemasaran berpengaruh positif terhadap Nilai Perusahaan

\section{Pengaruh Aset Tidak Berwujud Terhadap Nilai Perusahaan}

Menurut PSAK 19 (Ikatan Akuntan Indonesia, 2016), aset tidak berwujud ada lah aset non-moneter yang dapat diidentifikasi dan tidak mempunyai wujud fisik serta dimiliki untuk digunakan dalam meng- 
hasilkan pendapatan. Aset tidak berwujud diantaranya merek (brand) yang paling diutamakan perusahaan dalam usaha meningkatkan nilai perusahaan. Citra dan reputasi juga merupakan aset tak berwujud perusahaan yang juga dapat berkontribusi meningkatkan nilai perusahaan. Dengan demikian, informasi nilai aset tidak berwujud merupakan sinyal positif bagi investor (Widhiastuti dan Latrini, 2015).

Kegiatan pemasaran selain meningkatkan profitabilitas juga akan meningkatkan nilai merek atau yang biasa disebut ekuitas merek (brand equity). Brand equity adalah perbedaan respon konsumen terhadap suatu produk atau cara pemasarannya. Disamping itu, brand equity merepresentasikan persepsi konsumen terhadap suatu kinerja produk. Merek lebih dari sekedar nama dan simbol, bagi perusahaan merek adalah elemen kunci dalam membangun hubungan dengan masyarakat terutama konsumen. Ekuitas merek yang tinggi akan memberikan perusahaan banyak keunggulan kompetitif. Merek yang powerful akan mendapatkan tingkat konsumen dan loyalitas yang tinggi. Merek dengan ekuitas merek yang tinggi akan membawa kredibilitas yang tinggi, sehingga memudahkan perusahaan apabila ingin meluncurkan lini produk baru. Merek yang powerful juga akan memberikan perlindungan bagi perusahaan terhadap serangan kompetisi harga produk sejenis dari pesaing.

Aset tidak berwujud memiliki peran penting dalam mencapai tujuan dan strategi perusahaan serta dalam menentukan nilai pasar perusahaan (Trisnajuna dan Sisdyani, 2015). Manfaat yang diperoleh perusahaan adalah meningkatnya competitive advantage. Soraya dan Syafruddin (2013) serta Setijawan (2011) menyatakan bahwa variabel aset tidak berwujud berpengaruh positif terhadap nilai perusahaan. Lebih lanjut, Vomberg et al. (2015) menunjukkan bukti bahwa kekuatan merek (aset tidak berwujud) sangat menentukan nilai perusahaan. Dengan demikian, penelitian ini mengajukan hipotesis:
$\mathrm{H}_{2}$ : Aset Tidak Berwujud berpengaruh positif terhadap Nilai Perusahaan

\section{Pengaruh Profitabilitas Terhadap Nilai Perusahaan}

Peningkatan profitabilitas perusahaan menunjukkan kinerja perusahaan yang semakin baik dan prospek perusahaan yang semakin baik pula. Perusahaan yang memiliki prospek baik sangat disukai oleh investor karena dianggap akan memberikan tingkat pengembalian yang baik. Profitabilitas mengukur kinerja keuangan perusahaan dalam menghasilkan laba menggunakan aset yang dimiliki. Dengan demikian, investor menangkap peningkatan profitabilitas sebagai sinyal positif yang mampu meningkatkan nilai perusahaan. Oleh sebab itu, semakin tinggi profitabilitas maka semakin tinggi nilai perusahaan.

Peningkatan nilai perusahaan dapat ditentukan oleh earnings power aset perusahaan. Semakin tinggi earnings power semakin efisien perputaran aset dan semakin tinggi profit margin yang diperoleh perusahaan. Peningkatan profitabilitas perusahaan menunjukkan kinerja perusahaan yang semakin baik dan prospek perusahaan yang semakin baik pula. Hal ini akan mempengaruhi ekspektasi investor dan akhirnya harga saham yang menjadi komponen nilai perusahaan juga berubah. Banyak riset terdahulu yang mendukung dugaan bahwa profitabilitas berpengaruh positif terhadap nilai perusahaan antara lain Allazy (2013), Hardiyanti (2012), Hermuningsih (2013), Mahendra Dj et al. (2012), Nurhayati (2013), Putra dan Herawati (2013), Wahyuni et al. (2013), dan Widhiastuti dan Latrini (2015). Oleh sebab itu, penelitian ini mengajukan hipotesis:

$\mathrm{H}_{3}$ : Profitabilitas berpengaruh positif terhadap Nilai Perusahaan

\section{Pengaruh Likuiditas Terhadap Nilai Per- usahaan}

Likuiditas adalah kemampuan perusahaan dalam melunasi hutang-hutang jangka pendek tepat pada waktunya. 
Semakin tinggi likuiditas, maka semakin baik kemampuan perusahaan dalam memenuhi kewajiban jangka pendeknya. Likuiditas yang tinggi akan membuat perusahaan berada dalam kondisi yang aman, karena kecil kemungkinan akan terjadi kebangkrutan akibat tidak mampu membayar kewajiban, namun demikian, argumen tersebut sebelumnya adalah dari perspektif jangka pendek. Likuiditas yang terlalu tinggi dapat mengurangi kemampuan perusahaan dalam menghasilkan laba, karena banyaknya dana yang menganggur. Dengan demikian, likuiditas yang tinggi akan memberikan sinyal negatif kepada investor bahwa perusahaan kurang mampu memanfaatkan aset yang ada untuk menghasilkan laba yang lebih tinggi lagi (Nurhayati, 2013; Putra dan Herawati, 2013; Wijaya dan Purnawati, 2014). Biddle dan Hilary (2006) menyatakan bahwa kas (likuiditas) yang berlebih menimbulkan masalah keagenan. Manajer cenderung menghamburkan likuiditas untuk membangun kerajaan bisnis (empire building) dan investasi pada proyek yang tidak menguntungkan. Berdasarkan uraian tersebut, maka dirumuskan hipotesis sebagai berikut:

$\mathrm{H}_{4}$ : Likuiditas berpengaruh negatif terhadap Nilai Perusahaan

\section{Pengaruh Solvabilitas Terhadap Nilai Perusahaan}

Hutang merupakan salah satu sumber pendanaan perusahaan. Keputusan manajemen perusahaan dalam penggunaan hutang merupakan sinyal yang diberikan terhadap investor untuk menilai prospek perusahaan. Perusahaan dengan prospek yang baik akan memilih untuk menggunakan hutang sebagai alternatif pendanaan dibandingkan dengan pendanaan dengan ekuitas luar. Penggunaan pendanaan hutang dapat meningkatkan risiko kebangkrutan perusahaan, namun demikian, hal tersebut akan mendorong manajemen untuk bekerja lebih efisien sehingga kebangkrutan tidak terjadi (Rompas, 2013). Manajemen menggunakan modal yang salah satunya berasal dari hutang untuk melakukan pengembangan aktivitas usaha yang akan meningkatkan kemampuan perusahaan dalam menghasilkan laba (Sari dan Chabachib, 2013). Peningkatan jumlah hutang merupakan sinyal positif bagi investor. Ruan et al. (2011) menunjukkan bahwa struktur modal perusahaan (leverage) berpengaruh terhadap nilai perusahaan karena pengawasan dari kreditor lebih ketat untuk memastikan perusahaan memaksimalkan kinerjanya. Dengan demikian, penelitian ini berhipotesis bahwa:

$\mathrm{H}_{5}$ : Solvabilitas berpengaruh positif terhadap Nilai Perusahaan

\section{METODE PENELITIAN}

\section{Populasi dan Sampel}

Populasi dalam penelitian ini adalah perusahaan manufaktur sektor industri barang konsumsi yang tercatat di Bursa Efek Indonesia dari tahun 2012-2015 dengan total sebanyak 37 perusahaan dari 5 sub sektor di dalamnya. Industri barang konsumsi dipilih karena industri ini menghasilkan produk yang sehari-hari digunakan oleh konsumen dan pemasaran merupakan aktivitas dominan. Dengan demikian, pengamatan peran pemasaran dalam membentuk nilai perusahaan akan tercapai. Sektor industri ini dipilih karena termasuk sektor utama penggerak indeks pertumbuhan ekonomi menurut Kementerian Perindustrian Indonesia (2014), serta mendominasi hasil survei "Belanja Iklan Terbesar Periode 2014 dan Semester Awal 2015" menurut Nielsen (2015).

Penelitian ini menggunakan teknik purposive sampling untuk menentukan sampel yang diamati, oleh sebab itu, tingkat generalisasi hasil penelitian ini terbatas pada populasi yang memiliki karakteristik sama dengan sampel yang digunakan penelitian ini. Penelitian ini menggunakan 87 observasi untuk menguji hipotesis yang diajukan. Tabel 1 menyajikan data hasil proses seleksi sampel. Jenis data yang digunakan dalam penelitian ini adalah data sekunder, yaitu data yang tidak diperoleh 
Tabel 1

Kriteria Pengambilan Sampel - Metode Purposive Sampling

\begin{tabular}{|c|c|c|c|}
\hline No. & Kriteria Sampel & $\begin{array}{c}\text { Tidak Memenuhi } \\
\text { Syarat }\end{array}$ & Jumlah Sampel \\
\hline 1 & $\begin{array}{l}\text { Terdaftar di Bursa Efek Indonesia pada } \\
\text { tahun } 2015 \text { (Update } 30 \text { Desember 2015) }\end{array}$ & & 518 \\
\hline 2 & $\begin{array}{l}\text { Termasuk perusahaan sektor industri } \\
\text { barang konsumsi (consumer goods) }\end{array}$ & $(481)$ & 37 \\
\hline 3 & $\begin{array}{l}\text { Terdapat laporan keuangan audited } \\
\text { untuk tiap tahun 2012-2014 yang } \\
\text { dipublikasikan di Bursa Efek Indonesia }\end{array}$ & (3) & 34 \\
\hline 4 & $\begin{array}{l}\text { Tidak terdapat data outlier (data yang } \\
\text { sangat berbeda/ekstrim dibandingkan } \\
\text { dengan data-data lainnya) }\end{array}$ & (5) & 29 \\
\hline & Total sampel & & 29 \\
\hline & Total Observasi (3 tahun) & & 87 \\
\hline
\end{tabular}

Sumber: data hasil penelitian (diolah)

secara langsung dari subjek penelitian. Data sekunder adalah data yang berupa dokumen atau artikel tertentu. Data sekunder yang digunakan berupa laporan keuangan perusahaan sektor industri barang konsumsi yang terdiri dari laporan posisi keuangan dan laporan laba rugi, serta catatan atas laporan keuangan periode 2012-2014. Laporan keuangan bersumber dari publikasi perusahaan melalui website Bursa Efek Indonesia.

Data yang terdapat dalam laporan keuangan tersebut kemudian dijadikan sebagai dasar perhitungan untuk masingmasing variabel yang diteliti.

\section{Definisi Operasional Variabel}

\section{Aktivitas Pemasaran (Marketing_Ac)}

Grewal et al. (2009) dan Ciawi dan Hatane (2015) menyatakan bahwa dalam menghitung marketing expense di dalam sebuah penelitian yang menggunakan model regresi berganda dapat menggunakan logaritma dari nilai buku marketing expense tersebut.

Aktivitas Pemasaran $=$ LOG $($ Nilai Buku Beban Pemasaran).

Penggunaan logaritma beban pemasaran berguna untuk menormalkan distribusi error term dalam persamaan regresi yang digunakan penelitian ini selain untuk memerkecil standar deviasi.

\section{Aset Tidak Berwujud (IA_Disclosure)}

Aset tidak berwujud pada umumnya terdiri dari paten, merek, lisensi, izin, software, daftar data konsumen, sumber daya manusia, ilmu pengetahuan, goodwill, dan lain-lain. Sebagai bentuk transformasi data, nilai buku aset tidak berwujud disajikan dalam bentuk logaritma. Perhitungan aset tidak berwujud dilakukan menggunakan rumus berikut:

Aset Tidak Berwujud = LOG (Nilai Buku Aset Tidak Berwujud)

Penggunaan nilai buku aset tidak berwujud bertujuan untuk meningkatkan jumlah observasi. Kendati penggunaan nilai buku merek dagang lebih tepat secara teoretis untuk mengukur kekuatan perusahaan produk konsumen, banyak dari sampel yang dianalisis tidak memerinci nilai buku aset tidak berwujud sehingga berpotensi mengurangi jumlah observasi aset tidak berwujud, namun demikian, hal ini bisa meningkatkan risiko noisy pengukuran.

\section{Profitabilitas (ROA)}

Profitabilitas adalah kemampuan perusahaan untuk menghasilkan pendapatan. 
Rasio profitabilitas mengukur kemampuan perusahaan dalam menghasilkan laba dengan menggunakan sumber daya yang dimiliki perusahaan seperti aset produktif, modal pemilik dan modal kreditor, serta penjualan perusahaan. Profitabilitas dalam penelitian ini diukur dengan rasio Return on Assets. Penelitian ini menghitung profitabilitas dengan rumus:

Return on Asset $=\frac{\text { Net Income }}{\text { Total Asset }}$

\section{Likuiditas (CR)}

Likuiditas adalah kemampuan perusahaan dalam melunasi hutang-hutang jangka pendek tepat pada waktunya. Likuiditas yang tinggi akan membuat perusahaan berada dalam kondisi yang aman karena kecil kemungkinan akan terjadi kebangkrutan akibat tidak mampu membayar kewajiban. Likuiditas dalam penelitian ini diukur menggunakan Current Ratio sebagai berikut:

$$
\text { Current Ratio }=\frac{\text { Current Assels }}{\text { Currenl Liabilities }} \ldots . . . .
$$

\section{Solvabilitas (DER)}

Solvabilitas atau leverage adalah seberapa besar pendanaan di perusahaan berasal dari utang. Financial leverage adalah penggunaan hutang sebagai sumber pembiayaan perusahaan yang dapat diukur dengan menggunakan rasio leverage. Rasio leverage merupakan rasio yang digunakan untuk mengukur seberapa besar aktiva perusahaan dibiayai dengan hutang. Solvabilitas diproksikan dengan Debt to Equity Ratio yang mengukur tingkat penggunaan hutang (leverage) terhadap total shareholder's equity yang dimiliki perusahaan yang dihitung dengan:

\section{Debt to Equity Ratio = Total Debt \\ $\overline{\text { Total Shareholders'Equity }}$}

\section{Nilai Perusahaan}

Nilai perusahaan merupakan persepsi investor terhadap perusahaan, yang sering dikaitkan dengan harga saham. Memaksimalkan nilai perusahaan sangat penting artinya bagi suatu perusahaan, karena dengan memaksimalkan nilai perusahaan berarti juga memaksimalkan kemakmuran pemegang saham yang juga merupakan tujuan utama perusahaan. Harga saham yang tinggi membuat nilai perusahaan juga tinggi.

Variabel dependen dalam penelitian ini adalah Nilai Perusahaan (Firm_Value) yang diukur menggunakan rasio Tobin's $Q$. Rasio ini menandakan bahwa perusahaan tidak hanya terfokus pada satu tipe investor saja karena sumber pembiayaan operasional perusahaan bukan hanya dari investor saham saja tetapi juga dari pinjaman yang diberikan oleh kreditur.

Tobin's $Q=\frac{(\text { Share Outstanding } x \text { Closing Price })+\text { Total DEBT }+ \text { Imventory-Current Assets }}{\text { Total Assets }} \ldots$

\section{Teknik Analisis}

Analisis regresi digunakan dalam studi mengenai ketergantungan variabel dependen terhadap satu atau lebih variabel independen dengan tujuan untuk menjelaskan dan mengevaluasi hubungan antara variabel satu atau lebih variabel independen melalui sebuah persamaan regresi. Persamaan regresi yang digunakan adalah sebagai berikut: $Y=\beta_{0}+\beta_{1} \mathrm{ROA}+\beta_{2} \mathrm{CR}+$ $\beta_{3}$ DER $+\beta_{4}$ Marketing_Ac $+\beta_{5}$ IA_Disclosure +
Keterangan:

$\mathrm{Y}=$ Variabel Dependen

$\beta_{0} \quad=$ Nilai Intercept (Konstanta)

$\beta_{1-} \beta_{5} \quad=$ Konstanta Variabel Independen

ROA = Profitabilitas

CR $\quad=$ Likuiditas

DER $\quad=$ Solvabilitas

Marketing_Ac $=$ Aktivitas Pemasaran

IA_Disclosure $=$ Aset Tidak Berwujud

$\varepsilon=$ Error 
Uji asumsi klasik-uji normalitas, uji multikolinieritas, uji heterokedastisitasdilakukan untuk memastikan bahwa model regresi dan masing-masing variabelnya layak untuk dilakukan pengujian hipotesis. Uji koefisien determinasi juga dilakukan untuk mengetahui besarnya pengaruh variabel-variabel independen terhadap variabel dependen.

Sebagai analisis tambahan, penelitian ini akan menguji persamaan (7) menggunakan analisis data panel. Penggunaan analisis data panel memungkinkan penelitian ini menguji robustness hasil analisis menggunakan beberapa variasi alat uji. Penelitian ini akan memasukkan dummy tahun dalam persamaan (7) untuk mengendalikan ber- bagai variabel yang tidak terobservasi dan tidak terukur namun sangat mungkin membiaskan koefisien regresi estimasian persamaan (7). Lebih lanjut, penelitian ini juga mengestimasi standard error dengan teknik clustering pada level perusahaan untuk mengoreksi masalah heteroskedastisitas yang membiaskan nilai t-statistik.

\section{ANALISIS DAN PEMBAHASAN Analisis Statistik Deskriptif}

Statistik deskriptif menjabarkan data dalam bentuk numeris untuk diinterpretasikan. Tabel 2 menyajikan analisis statistik deskriptif masing-masing variabel penelitian. Rata-rata profitabilitas di perusahaan sampel adalah sebesar 0,1193

Tabel 2

Statistik Deskriptif

\begin{tabular}{llrrrr}
\hline \hline Variabel & N & Minimum & Maximum & Mean & \multicolumn{1}{c}{$\begin{array}{c}\text { Std. } \\
\text { Deviation }\end{array}$} \\
\hline Firm_Value & 87 &, 02 & 17,65 & 2,9116 & 3,43051 \\
Marketing_Ac & 87 &, 00 & 12,61 & 10,1447 & 2,66360 \\
IA_Disclosure & 87 &, 00 & 12,44 & 3,9734 & 5,18886 \\
ROA & 87 &,- 05 &, 43 &, 1193 &, 11173 \\
CR & 87 &, 05 & 7,73 & 2,3190 & 1,37591 \\
DER & 87 &, 03 & 2,11 &, 7683 &, 51524 \\
\hline
\end{tabular}

Sumber: data hasil penelitian (diolah)

dengan standar deviasi sebesar 0,11173. Profitabilitas paling kecil dimiliki oleh PT Prashida Aneka Niaga Tbk (PSDN) tahun 2014 sebesar -0,05. Berdasarkan hasil penelitian, diketahui perusahaan dengan data profitabilitas tertinggi adalah PT Unilever Indonesia Tbk (UNVR) pada tahun 2012 sebesar $43 \%$.

Rata-rata likuiditas di perusahaan sampel adalah sebesar 2,3190 dengan standar deviasi sebesar 1,37591. Likuiditas paling kecil dimiliki oleh PT Kedaung Indah Can Tbk (KICI) tahun 2012-2013 sebesar 0,05. Berdasarkan hasil penelitian, perusahaan dengan data likuiditas tertinggi adalah PT Mandom Indonesia, Tbk (TCID) pada tahun 2012 sebesar 7,73 atau 773\% perbandingan antara aset lancar dengan liabilitas lancar.
Rata-rata solvabilitas di perusahaan sampel adalah sebesar 0,7683 dengan standar deviasi sebesar 0,51524. Solvabilitas paling kecil dimiliki oleh Kalbe Farma Tbk (KLBF) tahun 2012 sebesar 0,03. Berdasarkan hasil penelitian, perusahaan dengan data solvabilitas terbesar adalah PT Unilever Indonesia Tbk (UNVR) pada tahun 2014 sebesar 2,11.

Rata-rata aktivitas pemasaran di perusahaan sampel adalah sebesar 10,1447 dengan standar deviasi sebesar 2,66360. Aktivitas pemasaran paling kecil dimiliki oleh PT Wilmar Cahaya Indonesia Tbk (CEKA) tahun 2014 dan PT Sekar Bumi Tbk (SKBM) tahun 2012-2014 sebesar 0.

Berdasarkan hasil penelitian, perusahaan dengan data aktivitas pemasaran ter- 
besar adalah PT Unilever Indonesia Tbk (UNVR) pada tahun 2013 sebesar 4,1 trilyun rupiah. Pada tahun 2013, perusahaan sedang gencar memperkenalkan produkproduk barunya yaitu Teh Sari Melati, varian parfum AXE Apollo, dan es krim Magnum Mini, serta memperkuat brand image produk Sunlight dengan melakukan Project Sunlight, yaitu program yang bermisi sosial untuk menggandeng masyarakat mempromosikan gaya hidup yang lebih sehat dan lebih lestari. Pada tahun sebelumnya pula perusahaan baru saja meluncurkan produk hair care TRESemme dan varian parfum AXE Anarchy.

Rata-rata aset tidak berwujud di perusahaan sampel adalah sebesar 3,9734 dengan standar deviasi sebesar 5,18886. Aset tidak berwujud paling kecil sebesar 0 dimiliki oleh 18 perusahaan yang tidak mengungkapkan nilai aset tidak berwujud. Berdasarkan hasil penelitian, perusahaan dengan data aset tidak berwujud tertinggi adalah PT Indofood Sukses Makmur Tbk (INDF) pada tahun 2014 sebesar kurang lebih 2,7 triliun rupiah.

Rata-rata nilai perusahaan di perusahaan sampel adalah sebesar 2,9116 dengan standar deviasi sebesar 3,43051. Nilai perusahaan paling besar dimiliki oleh PT Unilever Indonesia Tbk (UNVR) tahun 2014 sebesar 17,65, sedangkan yang paling kecil dimiliki oleh PT Martina Berto Tbk (MBTO) tahun 2014 sebesar 0,02. Hasil analisis statistik deskriptif menunjukkan beberapa fakta menarik. Rata-rata nilai perusahaan sampel adalah sebesar 2,9116 dengan nilai maksimum 17,65 yang menandakan banyak sampel yang memiliki nilai perusahaan rendah.

Fenomena yang sama ditemukan pada aset tidak berwujud yang nilai rata-ratanya mendekati nilai minimalnya. Hal ini berpotensi mengurangi kekuatan hasil analisis regresi yang dilakukan. Selain itu, pengeluaran beban pemasaran rata-rata mencapai 10 miliar rupiah dengan nilai maksimal 1 triliun rupiah. Pengeluaran pemasaran terbesar dilakukan oleh PT
Unilever Indonesia, Tbk yang memiliki variasi produk barang konsumsi terbanyak dengan menyewa banyak selebriti atau tokoh masyarakat sebagai brand ambassador. Sebagaimana dijelaskan oleh Anjum et al. (2012) dan Ogunsiji (2012), penggunaan selebriti sebagai duta merek secara empiris mampu meningkatkan kinerja pemasaran dan penjualan.

\section{Uji Asumsi Klasik}

Penelitian ini hanya menggunakan tiga uji asumsi klasik saja yaitu normalitas, multikolinieritas, dan heteroskedastisitas, karena data penelitian bersifat panel yaitu kombinasi cross-section dan time-series. Hasil uji multikolinieritas pada tabel 3 panel A menunjukkan bahwa tidak ada korelasi antar variabel independen dalam persamaan (7) ditunjukkan oleh nilai tolerance lebih besar dari 0,10 dan nilai VIF kurang dari 10. Uji normalitas pada tabel 3 panel B menggunakan Kolmogorov-Smirnov menunjukkan bahwa residual (error) persamaan (7) terdistribusi normal dengan ditunjukkan tingkat signifikansi koefisien Kolmogorov-smirnov yang lebih dari $5 \%$.

Hasil uji Glejser untuk mendeteksi heteroskedastisitas ditampilkan di tabel 3 panel C. Berdasarkan hasil uji Glejser, model penelitian ini mengalami masalah heterokedastisitas yang berarti varian error tidak sama untuk semua pengamatan crosssection yang ditunjukkan oleh signifikansi koefisien aset tidak berwujud.

Karena data panel sering memunculkan varians error yang heteroskedastis sebab cross-section menghimpun data dengan berbagai ukuran (besar, sedang, kecil). Hal ini disebabkan pula oleh sedikitnya jumlah perusahaan yang mengungkapkan nilai aset tidak berwujudnya dalam laporan keuangan. Masalah heteroskedastisitas ini akan dianalisis lebih lanjut di bagian analisis tambahan.

\section{Uji Hipotesis}

Analisis regresi linier berganda dilakukan untuk membuktikan pengaruh 
variabel independen terhadap variabel dependen. Hasil uji regresi ditampilkan di tabel 4.

Nilai Konstanta sebesar -2,496. Hal ini berarti bahwa jika Profitabilitas (ROA),
Likuiditas (CR), Solvabilitas (DER), Aktivitas Pemasaran (Marketing_Ac), dan Aset Tidak Berwujud (IA_Disclosure) tetap dan tidak mengalami perubahan maka Nilai Perusahaan (Y) akan turun sebesar 2,496.

Tabel 3

Hasil Uji Asumsi Klasik

Panel A: Uji Multikolinieritas

\begin{tabular}{lcc}
\hline \multicolumn{1}{c}{ Variabel } & Tolerance & VIF \\
\hline ROA & 0.894 & 1.178 \\
CR & 0.65 & 1.538 \\
DER & 0.675 & 1.482 \\
Marketing_Ac & 0.847 & 1.181 \\
IA_Disclosure & 0.839 & 1.191
\end{tabular}

Panel B: Uji Normalitas

\begin{tabular}{lcc}
$\begin{array}{l}\text { Kolmogorov-Smirnov Z } \\
\text { Asymp. Sig. (2-tailed) }\end{array}$ & \multicolumn{2}{c}{, 646} \\
Panel C: Uji Heterokedastisitas & & \\
\hline Variabel & t hitung & Signifikansi \\
\hline ROA & 1,800 & 0,076 \\
CR & 0,50 & 0,619 \\
DER & 1,375 & 0,173 \\
Marketing_Ac & $-0,798$ & 0,427 \\
IA_Disclosure & 3,934 & 0,000 \\
\hline
\end{tabular}

Sumber: data hasil penelitian (diolah)

Tabel 4

Hasil Uji Regresi - Basic

\begin{tabular}{lrrc}
\hline \hline \multicolumn{1}{c}{ Variabel } & Koefisien & \multicolumn{1}{c}{ t } & Signifikansi \\
\hline Marketing_Ac & 0,177 & 3,21 & $0,002^{* *}$ \\
IA_Disclosure & 0,4 & 1,4 & 0,165 \\
ROA & 27,866 & 21,266 & $0,000^{* * *}$ \\
CR & $-0,316$ & $-2,603$ & $0,011^{* *}$ \\
DER & 1,129 & 3,543 & $0,001^{* * *}$ \\
Konstanta & $-2,496$ & $-3,458$ & $0,001^{* * *}$ \\
\hline Adjusted $\mathrm{R}^{2}=0,867$ & & & \\
Signifikansi $\mathrm{F}=0,000$ & & & \\
\hline
\end{tabular}

Sumber: data hasil penelitian (diolah);

Keterangan: ** signifikan pada level 5\%; ${ }^{* *}$ signifikan pada level 1\%

Hal ini disebabkan tidak adanya informasi yang masuk ke investor sehingga investor akan menurunkan estimasi nilai perusahaan. Koefisien ROA sebesar 27,866 berimplikasi jika profitabilitas bertambah satu per- sen maka nilai perusahaan akan meningkat 27,866 persen dengan asumsi variabel lain tetap. Koefisien CR sebesar -0,316 berarti apabila likuiditas meningkat satu persen maka nilai perusahaan akan menurun 0,316 
persen, ceteris paribus. Koefisien DER sebesar 1,129 berarti apabila solvabilitas meningkat satu persen maka nilai perusahaan akan meningkat 1,129 persen dengan asumsi ceteris paribus tetap. Jika variabel independen lain tetap, koefisien Marketing_Ac sebesar 0,177 yang berarti apabila aktivitas pemasaran meningkat 1 satuan maka nilai perusahaan akan meningkat 0,177 persen.

Tabel 4 di atas menunjukkan bahwa penelitian ini berhasil mengkonfirmasi hipotesis yang diusulkan kecuali untuk pengaruh aset tidak berwujud terhadap nilai perusahaan (hipotesis 2). Variasi variabel nilai perusahaan mampu dijelaskan oleh variabel-variabel independen sebesar 86,7\% (adj $R^{2}$ ). Signifikansi nilai $\mathrm{F}$ lebih kecil dari $1 \%$ yang berarti model penelitian ini mampu menjelaskan variasi variabel nilai perusahaan. Sekali lagi, hal ini mengonfirmasi bukti dari uji asumsi klasik tentang kelayakan model.

\section{Analisis tambahan}

Untuk menunjukkan bahwa simpulan statistik hasil penelitian ini tidak terganggu oleh masalah heteroskedastisitas, penelitian ini melakukan uji regresi model penelitian ini dengan tidak menyertakan variabel aset tidak berwujud. Selain itu, penelitian ini juga mengoreksi masalah heteroskedastisitas dengan memanfaatkan analisis data panel. Sesuai dengan hasil uji Glejser dalam panel C tabel 3, terdapat korelasi positif antara pengungkapan aset tak berwujud dengan error estimasian. Hal ini dikoreksi dengan menghilangkan variabel pengungkapan aset takberwujud (IA_Disclosure) dari model. Tabel 5 menyajikan hasil uji regresi tanpa variabel IA_Disclosure.

Tabel 5

Hasil Uji Regresi - Eliminasi Aset Tidak Berwujud

\begin{tabular}{lrrc}
\hline \hline \multicolumn{1}{c}{ Variabel } & Koefisien & \multicolumn{1}{c}{ t } & Signifikansi \\
\hline Marketing_Ac & 0,199 & 3,80 & $0,000^{* * *}$ \\
ROA & 28,372 & 22,22 & $0,000^{* * *}$ \\
CR & $-0,325$ & $-2,67$ & $0,009^{* * *}$ \\
DER & 1,122 & 3,53 & $0,001^{* * *}$ \\
Konstanta & $-2,586$ & $-3,62$ & $0,001^{* * *}$ \\
\hline Adjusted $\mathrm{R}^{2}=0,867$ & & & \\
Signifikansi $\mathrm{F}=0,000$ & & & \\
\hline
\end{tabular}

Sumber: data hasil penelitian (diolah);

Keterangan: ** signifikan pada level 5\%; ** signifikan pada level 1\%

Tabel 5 menampilkan hasil yang tidak jauh berbeda dengan tabel 4 . Koefisien kegiatan pemasaran lebih besar dari sebelumnya dan tetap signifikan pada level $1 \%$. Variabel profitabilitas, likuiditas, dan solvabilitas juga masih menunjukkan tanda koefisien regresi yang konsisten dengan tabel 4. Hal ini menunjukkan bahwa simpulan statistik pengaruh kegiatan pemasaran terhadap nilai perusahaan tidak terganggu oleh masuk dan tidaknya aset tidak berwujud dalam analisis regresi.

Lebih lanjut, penelitian ini mengesti masi persamaan (7) menggunakan teknik analisis data panel untuk mengatasi persoalan heteroskedastisitas. Secara lebih spesifik, penelitian ini menambahkan variabel dummy tahun pada persamaan (7) serta mengestimasi standard error menggunakan teknik clustering pada level perusahaan. Variabel-variabel yang secara konstan ada lintas-waktu namun tidak diobservasi dan tidak terukur akan menjadi bagian dari error persaman (7). Jika variabel tersebut berkorelasi dengan variabel-variabel independen dalam model, koefisien regresi yang dihasilkan merupakan koefisien regresi yang bias dan tidak konsisten. Menyertakan 
variabel dummy tahun pada persamaan regresi berguna untuk mengontrol variasi lintas-waktu yang secara konstan berada pada error term regresi persamaan (7) (Gow et al., 2010). Koefisien fixed effect tahun menyerap berbagai variabel yang secara konstan ada lintas-waktu namun tidak diobservasi dan tidak terukur.

Heteroskedastisitas juga menimbulkan masalah pada estimasi standard error regresi yang menjadi basis perhitungan t-statistik sehingga kerap menghasilkan kesalahan tipe 2 dalam regresi. Kesalahan tipe 2 dalam analisis regresi adalah gagal menolak hipotesis yang sebenarnya salah yang disebabkan estimasi $\mathrm{t}$-statistik yang terlalu tinggi akibat gangguan pada standard error. Mengestimasi standard error secara clustering pada level perusahaan berguna untuk mengatasi kesalahan tipe 2 dengan meningkatkan standard error dan menurunkan nilai t-statistik (Petersen, 2009). Tabel 6 menampilkan hasil regresi dengan teknik analisis data panel. Fixed effect tahun dan clustered standard error pada level perusahaan dimasukkan dalam teknik estimasi untuk mengontrol variasi lintas-tahun dan heteroskedastisitas. Hasil di tabel 6 menunjukkan bahwa kegiatan pemasaran tetap berpengaruh positif terhadap nilai perusahaan.

Nilai koefisien Marketing_Ac konsisten dengan tabel 6 yaitu 0,199 dan lebih tinggi dari koefisien pada tabel 5. Lebih lanjut, aset tidak berwujud tetap tidak berpengaruh terhadap nilai perusahaan. Variabel ROA, $C R$, dan DER juga menunjukkan hasil yang tidak jauh berbeda dari tabel 4 dan 5 . Kendati t-statistik telah dikoreksi sehingga menjadi lebih kecil, hasil analisis statistik penelitian ini tetap robust dengan berbagai variasi estimasi.

Tabel 6

Hasil Uji Regresi - Analisis Data Panel

\begin{tabular}{lrrc}
\hline \hline \multicolumn{1}{c}{ Variabel } & Koefisien & \multicolumn{1}{c}{$\mathbf{t}$} & Signifikansi \\
\hline Marketing_Ac & 0,199 & 3,80 & $0,000^{* * *}$ \\
IA_Disclosure & 0,039 & 1,07 & 0,296 \\
ROA & 28,2 & 11,41 & $0,000^{* * *}$ \\
CR & $-0,322$ & $-2,64$ & $0,013^{* *}$ \\
DER & 1,107 & 2,28 & $0,031^{* *}$ \\
Konstanta & $-2,797$ & $-3,31$ & $0,003^{* * *}$ \\
\hline
\end{tabular}

Fixed effect: Tahun

Clustered standard error: Perusahaan

Adjusted $\mathrm{R}^{2}=0,886$

Signifikansi $\mathrm{F}=0,000$

Sumber: data hasil penelitian (diolah);

Keterangan: ** signifikan pada level 5\%; $* * *$ signifikan pada level 1\%

Pengaruh Aktivitas Pemasaran Terhadap Nilai Perusahaan

Berdasarkan hasil uji statistik yang telah dilakukan, diketahui bahwa variabel Aktivitas Pemasaran (Marketing_Ac) memili ki tingkat signifikansi yang lebih kecil dari $0,05(a=5 \%)$. Hasil uji statistik juga menunjukkan bahwa variabel Aktivitas Pemasaran mempunyai nilai koefisien positif atau searah terhadap Nilai Perusahaan. Hal ini mengindikasikan bahwa setiap kenaikan Aktivitas Pemasaran akan menyebabkan kenaikan Nilai Perusahaan. Dengan demikian, $\mathrm{H}_{1}$ tidak ditolak yang berarti bahwa Aktivitas Pemasaran berpengaruh positif terhadap Nilai Perusahaan.

Penelitian ini membuktikan bahwa informasi tentang aktivitas pemasaran yang dilakukan perusahaan mampu dan relevan dalam memberi sinyal kepada investor, 
sehingga dari informasi tersebut akan timbul reaksi yang akan berpengaruh terhadap nilai perusahaan. Koefisien aktivitas pemasaran menunjukkan nilai yang positif dan signifikan. Hasil penelitian ini konsisten dengan penelitian yang dilakukan oleh Ciawi dan Hatane (2015), Irawan dan Hatane (2015), serta Serenia dan Hatane (2015). Hasil penelitian tersebut menunjuk kan bahwa aktivitas pemasaran berpengaruh positif terhadap harga saham. Saat harga saham meningkat, maka nilai perusahaan pun ikut meningkat. Hal ini menandakan bahwa informasi tentang semakin besarnya beban pemasaran yang dikeluarkan perusahaan menjadi sinyal positif bagi investor yang akan berdampak terhadap semakin besarnya nilai perusahaan. Dengan dilakukannya kegiatan pemasaran seperti iklan dan promosi maka perusahaan akan mudah dikenali oleh investor. Dengan semakin kenalnya investor pada perusahaan, investor akan lebih mudah untuk berkeyakinan bahwa perusahaan mampu mengolah sumber dana dengan baik. Gencarnya aktivitas pemasaran menandakan bahwa perusahaan sedang dalam kondisi keuangan yang optimal dan menjanjikan pertumbuhan dengan dilakukannya aktivitas pemasaran tersebut. Sebagaimana pernyataan Edeling dan Fischer (2016) bahwa pemasaran mengambil peran signifikan dalam menentukan nilai perusahaan. Mentalitas akuntansi yang membebankan sekaligus biaya pemasaran dilandasi ketidakmampuan menghitung manfaat ekonomi pemasaran. Kendati demikian, penelitian ini dan penelitian terdahulu sepakat bahwa kegiatan pemasaran memiliki manfaat ekonomi dalam pembentukan nilai perusahaan. Temuan ini berimplikasi pada kebijakan akuntansi atas pembebanan biaya pemasaran dan pengukuran manfaat ekonominya.

\section{Pengaruh Aset Tidak Berwujud Terhadap Nilai Perusahaan}

Berdasarkan hasil uji statistik yang telah dilakukan, diketahui bahwa variabel
Aset Tidak Berwujud (IA_Disclosure) memiliki tingkat signifikansi yang lebih besar dari 0,05 $(\alpha=5 \%)$ kendati mempunyai nilai koefisien positif atau searah terhadap Nilai Perusahaan. Sebagai konsekuensinya, $\mathrm{H}_{5}$ ditolak yang berarti bahwa aset takberwujud tidak berkontribusi dalam pembentukan nilai perusahaan.

Penelitian ini tidak berhasil membuktikan bahwa informasi tentang aset tidak berwujud yang dimiliki perusahaan mampu memberi sinyal kepada investor. Koefisien regresi aset tidak berwujud adalah positif namun tidak signifikan. Fakta ini menunjukkan bahwa kendati tidak signifikan, koefisien aset tidak berwujud yang positif telah sesuai dengan ekspektasi teori bahwa perusahaan produk konsumen sangat mengandalkan inovasi (pengetahuan) selain aset berwujudnya. Hal ini sesuai dengan pernyataan Hall (1992) dan Gardberg dan Fombrun (2006) yang menegaskan pentingnya kepemilikan pengetahuan (inovasi/aset tidak berwujud) dalam industri barang konsumen Tidak signifikannya koefisien aset tidak berwujud bisa jadi disebabkan oleh sedikitnya jumlah perusahaan di sektor industri barang konsumsi yang mengungkapkan nilai aset tidak berwujud dalam laporan keuangannya. Png (2017) menyatakan bahwa sebagian besar perusahaan memilih untuk menyimpan inovasi yang ditemukan sebagai rahasia perusahaan (trade secrets) daripada sebagai aset tidak berwujud yang formal seperti paten. Rahasia perusahaan lebih fleksibel dan tidak terbatas waktu daripada paten yang berbatas waktu dan memerlukan banyak biaya untuk mendaftarkannya.

Dari segi statistik, sedikitnya jumlah perusahaan di sektor industri barang konsumsi yang mengungkapkan nilai aset tidak berwujud dalam laporan keuangannya akan menyebabkan standar deviasi tinggi dan menurunkan nilai t-statistik. Hal ini terlihat dari statistik deskriptif pada tabel 2. Kendati nilai maksimum aset tidak berwujud adalah 12 namun rata-ratanya mendekati nilai minimum nol yaitu sebesar 
3,9. Di sisi lain, secara konseptual, tidak adanya pengaruh aset tidak berwujud terhadap nilai perusahaan bisa jadi disebabkan oleh perusahaan yang lebih memilih menggunakan metode pencatatan cost method daripada menyesuaikannya dengan fair value (revaluation model). Liang dan Riedl (2013) menunjukkan bukti bahwa penggunaan nilai wajar lebih baik dalam menghasilkan prediksi nilai perusahaan daripada nilai historis. Kondisi pasar dan ekonomi Indonesia diduga belum cukup bagus untuk menghasilkan estimasi nilai wajar aset tidak berwujud yang memadai sehingga penggunaan historical cost masih dominan. Hal ini sesuai dengan prediksi Christensen dan Nikolaev (2013) yang menyatakan bahwa penggunaan nilai wajar lebih sedikit dari pada penggunaan historical cost untuk menilai aset nonkeuangan. Penggunaan nilai wajar hanya sebatas jika terdapat estimasi yang handal dan mencerminkan kinerja perusahaan.

Standar akuntansi memberikan diskresi yang besar kepada manajemen untuk menentukan metode penilaian serta amortisasi (atau tidak diamortisasi) aset tidak berwujud. Sebagai contoh, PSAK 19 (Ikatan Akuntan Indonesia, 2016) memberikan diskresi kepada manajemen untuk memilih metode biaya atau metode revaluasi dalam menilai aset tidak berwujud. PSAK 19 (2017) juga memberikan diskresi yang sangat luas saat mengevaluasi penurunan nilai aset tidak berwujud yang umurnya tidak dapat ditentukan (invinite).

Dengan demikian, nilai manfaatnya bisa jadi menyimpang dari nilai bukunya. Eisfeldt dan Papanikolaou (2014) menandaskan bahwa karakter unik aset tidak berwujud membuat nilai intrinsiknya sulit ditangkap baik oleh nilai buku maupun nilai pasar, oleh sebab itu, investor tidak mengkapitalisasi aset tidak berwujud untuk membentuk nilai perusahaan.

Lebih lanjut, Dechow dan Skinner (2000) juga menyatakan bahwa aset tidak berwujud sangat berpotensi menjadi alat manajemen laba perusahaan. Relevansi nilai aset tidak berwujud bisa juga terganggu oleh penggunaan diskresi manajemen secara oportunis dalam mengatur nilai amortisasi dan impairment yang terjadi pada aset tidak berwujud tersebut (Dechow dan Skinner, 2000). Hal-hal tersebut akan membuat relevansi aset tidak berwujud berkurang. Untuk sektor barang konsumsi, semakin pengamatan terfokus pada peningkatan nilai aset tidak berwujud maka seharusnya investor akan lebih diuntungkan dibandingkan jika terlalu fokus pada aset berwujud, sebab perusahaan sektor barang konsumsi memiliki aset tidak berwujud berupa brand yang harus terus ditingkatkan nilainya agar mampu bersaing dengan produk-produk sejenis milik pesaing.

\section{Pengaruh Profitabilitas Terhadap Nilai Perusahaan}

Berdasarkan hasil uji statistik, diketahui bahwa variabel Profitabilitas (ROA) memiliki tingkat signifikansi sebesar yang lebih kecil dari 0,05 $(\alpha=5 \%)$. Hasil uji statistik juga menunjukkan bahwa variabel Profitabilitas mempunyai nilai koefisien positif atau searah terhadap Nilai Perusahaan. Nilai koefisien profitabilitas juga merupakan yang terbesar dibandingkan variabel lainnya. Hal ini mengindikasikan bahwa setiap kenaikan profitabilitas akan menyebabkan peningkatan nilai perusahaan, dan bersifat dominan dibandingkan faktor lainnya. Dengan demikian, $\mathrm{H}_{3}$ diterima yang berarti bahwa Profitabilitas berpengaruh positif terhadap Nilai Perusahaan. Penelitian ini membuktikan bahwa informasi tentang profitabilitas perusahaan mampu dan relevan dalam memberi sinyal kepada investor, sehingga dari informasi tersebut akan timbul reaksi yang akan berpengaruh terhadap nilai perusahaan. Hasil penelitian ini konsisten dengan penelitian yang dilakukan oleh Allazy (2013), Hardiyanti (2012), Hermuningsih (2013), Mahendra Dj et al. (2012), Nurhayati (2013), Putra dan Herawati (2013), Wahyuni et al. (2013), dan Widhiastuti dan Latrini (2015). Hasil 
penelitian tersebut menyatakan bahwa profitabilitas yang diproksikan oleh Return on Assets berpengaruh positif terhadap nilai perusahaan.

Semakin tinggi tingkat profitabilitas maka semakin tinggi pula nilai perusahaan. Semakin perusahaan mampu untuk terus menghasilkan laba dari tahun ke tahun, mengindikasikan bahwa saat ini perusahaan sedang dalam kondisi operasional yang optimal. Hal ini akan ditangkap oleh investor sebagai sinyal positif bagi perusahaan untuk dapat menghasilkan tingkat pengembalian yang tinggi pula. Dengan demikian, nilai perusahaan pun terus meningkat seiring dengan meningkatnya jumlah investasi dana dari investor.

\section{Pengaruh Likuiditas Terhadap Nilai Perusahaan}

Berdasarkan hasil uji statistik yang telah dilakukan, diketahui bahwa variabel Likuiditas (CR) memiliki tingkat signifikansi yang lebih kecil dari 0,05 ( $\alpha=5 \%$ ). Hasil uji statistik juga menunjukkan bahwa variabel Likuiditas mempunyai nilai koefisien negatif atau berlawan terhadap Nilai Perusahaan. Hal ini mengindikasikan bahwa setiap kenaikan likuiditas akan menyebabkan penurunan nilai perusahaan. Oleh sebab itu, $\mathrm{H}_{4}$ diterima yang berarti bahwa Likuiditas berpengaruh negatif terhadap Nilai Perusahaan. Penelitian ini membuktikan bahwa informasi tentang likuiditas perusahaan mampu dan relevan dalam memberi sinyal kepada investor, sehingga dari informasi tersebut akan timbul reaksi yang akan berpengaruh terhadap nilai perusahaan.

Hasil penelitian ini konsisten dengan penelitian Adnyana dan Badjra (2014), Nurhayati (2013), Putra dan Herawati (2013), dan Wijaya dan Purnawati (2014) yang menyatakan bahwa likuiditas yang diproksikan oleh Current Ratio berpengaruh negatif terhadap nilai perusahan. Likuiditas yang terlalu tinggi dapat mengurangi kemampuan perusahaan dalam menghasilkan laba karena banyaknya dana yang menganggur. Adanya piutang tak tertagih dan persediaan yang belum terjual akan membuat current ratio tinggi seolah-olah perusahaan berada dalam kondisi yang likuid. Likuiditas yang tinggi tidak selalu menguntungkan karena berpeluang menjadi dana menganggur (idle cash) dan akan menimbulkan opportunity cost yang besar yang sebenarnya dapat digunakan untuk investasi menguntungkan dan profitable bagi perusahaan, seperti ekspansi usaha atau peningkatan investasi.

\section{Pengaruh Solvabilitas Terhadap Nilai Perusahaan}

Berdasarkan hasil uji statistik yang telah dilakukan, diketahui bahwa variabel Solvabilitas (DER) memiliki tingkat signifikansi yang lebih kecil dari 0,05 ( $\alpha=5 \%)$. Hasil uji statistik juga menunjukkan bahwa variabel Solvabilitas mempunyai nilai koefisien positif atau searah terhadap Nilai Perusahaan. Hal ini mengindikasikan bahwa setiap kenaikan Solvabilitas akan menyebabkan kenaikan Nilai Perusahaan. Dengan demikian, $\mathrm{H}_{5}$ diterima yang berarti bahwa Solvabilitas berpengaruh positif terhadap Nilai Perusahaan.

Penelitian ini membuktikan bahwa informasi tentang solvabilitas perusahaan mampu dan relevan dalam memberi sinyal kepada investor, sehingga dari informasi tersebut akan timbul reaksi yang akan berpengaruh terhadap nilai perusahaan. Hasil penelitian ini konsisten dengan penelitian yang dilakukan oleh Rompas (2013) dan Sari dan Chabachib (2013). Hasil penelitian tersebut menunjukkan bahwa solvabilitas yang diproksikan dengan Debt to Equity Ratio (DER) memiliki pengaruh positif terhadap nilai perusahaan. Penggunaan pendanaan hutang dapat meningkatkan risiko atas kebangkrutan perusahaan, namun hal tersebut akan mendorong manajemen untuk bekerja lebih keras dan efisien sehingga kebangkrutan tidak terjadi. Modal berupa hutang tersebut akan digunakan manajemen untuk melakukan ekspansi atau peningkatan aktivitas 
perusahaan, sehingga peningkatan jumlah hutang merupakan sinyal positif bagi investor.

\section{Implikasi Penelitian \\ Peran Aktivitas Pemasaran Dalam Sektor Industri Barang Konsumsi}

Peranan pemasaran dalam sektor industri barang konsumsi adalah sangat penting. Bukan tidak mungkin justru pemasaran yang menjadi jantung sebuah usaha di sektor ini. Perusahaan sektor konsumsi berfokus pada barang kebutuhan sehari-hari manusia. Karena sifat pemakaiannya yang intens menimbulkan persaingan yang ketat bagi perusahaan di sektor industri ini. Perusahaan harus mampu menciptakan diferensiasi produk dibandingkan produk sejenis lainnya milik pesaing, yaitu dengan melakukan aktivitas pemasaran yang efektif. Jika tidak, maka cakupan pasar yang didapat akan sangat kecil. Produk tanpa value yang tinggi hanya akan dibeli oleh konsumen tetap atau konsumen yang tidak memiliki pilihan lain, berlawanan dengan tujuan utama dari pemasaran itu sendiri yaitu untuk mempengaruhi masyarakat untuk membeli suatu produk.

Pemasaran tidak memiliki sebuah bentuk baku. Pemasaran yang dinilai berhasil adalah pemasaran yang mampu menghasilkan penjualan dan citra baik dipikiran masyarakat. Perusahaan bisa mengungkapkan keunggulan produk yang tidak dimiliki produk sejenis lainnya atau menggunakan kata-kata hiperbola untuk membuatnya mudah diingat dipikiran masyarakat. Tagline dan konten iklan yang unik dan menarik akan menimbulkan minat di benak konsumen dan menjadikan produk tersebut sebagai alternatif untuk dibeli. Perusahaan harus terus mampu memuaskan konsumen lama sambil terus menggaet konsumen baru. Kendati akuntansi masih menghadapi kesulitan menilai manfaat ekonomi aktivitas pemasaran (Sidhu dan Roberts, 2008), manfaat riil aktivitas pemasaran dalam meningkatkan penjualan dan nilai perusahaan tidak bisa diabaikan.

\section{Relevansi Aset Tidak Berwujud}

Hasil penelitian menunjukkan bahwa variabel aset tidak berwujud kehilangan relevansinya dalam memprediksi nilai perusahaan. Hal ini disebabkan oleh sedikitnya jumlah perusahaan di sektor industri barang konsumsi yang mengungkapkan nilai aset tidak berwujud dalam laporan keuangannya. Secara konseptual, tidak berpengaruhnya aset tidak berwujud terhadap nilai perusahaan disebabkan oleh perusahaan yang lebih memilih menggunakan metode pencatatan cost method daripada menyesuaikannya dengan fair value (revaluation model), atau disebabkan oleh diskresi manajemen dalam mengatur nilai amortisasi dan impairment yang terjadi pada aset tidak berwujud tersebut. Hal-hal tersebut akan membuat relevansi data berkurang, oleh karena itu Dewan Standar Akuntansi Keuangan dapat meninjau kembali PSAK 19 yang berkaitan dengan aset tidak berwujud.

\section{Relevansi Kinerja Keuangan}

Hasil penelitian menunjukkan bahwa ketiga variabel yang mewakili kinerja keuangan, yaitu profitabilitas, likuiditas, dan solvabilitas memiliki pengaruh positif dan terhadap nilai perusahaan. Hal ini menandakan bahwa informasi akuntansi terkait kinerja keuangan perusahaan masih relevan untuk memprediksi nilai perusahaan, sebab informasi mengenai hal tersebut berkaitan dengan prospek perusahaan saat ini dan di masa depan. Hal ini juga menegaskan bahwa teori pensinyalan (signaling) masih relevan untuk menjelaskan hubungan data akuntansi dengan prediksi nilai perusahaan.

\section{Keterbatasan Penelitian}

Terdapat beberapa fakta yang tidak bisa diatasi oleh penelitian ini sehingga membatasi hasil penelitian. Pertama, terdapat beberapa perusahaan yang tidak mempublikasikan laporan keuangan yang sudah diaudit antara tahun 2012-2014. Hal ini menyebabkan jumlah sampel dan jumlah pengamatan semakin kecil. Laporan yang 
digunakan hanya yang audited dengan alasan untuk memperkecil tingkat kesalahan pemberian informasi keuangan yang dikhawatirkan akan menimbulkan kesalahan dalam pengambilan keputusan. Laporan audited menandakan bahwa data-data keuangan bersifat wajar dan telah dilaporkan sesuai dengan pelaporan keuangan yang berlaku umum, sehingga layak digunakan sebagai sumber data penelitian yang valid. Kedua, beberapa data perusahaan dari sektor barang konsumsi terdapat outlier sebagai akibat terjadinya stock split atau laba negatif, sehingga tidak dimasukkan sebagai sampel penelitian. Hal ini dilakukan agar asumsi normalitas data dapat terpenuhi. Ketiga, banyak perusahaan yang tidak mengungkapkan nilai aset tidak berwujud dalam laporan keuangannya, sehingga banyak pengamatan yang bernilai nol dan menyebabkan standar deviasi tinggi.

\section{SIMPULAN DAN SARAN Simpulan}

Berdasarkan hasil analisis data dan pembahasan hasil penelitian yang telah dikemukakan sebelumnya, dapat disimpulkan beberapa hal penting sebagai berikut. Pertama, aktivitas pemasaran berpengaruh terhadap nilai perusahaan. Informasi mengenai aktivitas pemasaran perusahaan bisa digunakan untuk memprediksi nilai perusahaan. Semakin tinggi aktivitas pemasaran maka semakin tinggi pula nilai perusahaan. Kedua, aset tidak berwujud tidak berpengaruh terhadap nilai perusahaan. Informasi mengenai aset tidak berwujud perusahaan tidak bisa digunakan untuk memprediksi nilai perusahaan. Semakin tinggi aset tidak berwujud tidak terlalu berpengaruh dalam peningkatan nilai perusahaan. Hal ini disebabkan oleh sedikitnya jumlah perusahaan di sektor industri barang konsumsi yang mengungkapkan nilai aset tidak berwujud dalam laporan keuangannya. Ketiga, profitabilitas berpengaruh terhadap nilai perusahaan. Informasi mengenai profitabilitas bisa digunakan untuk memprediksi nilai perusahaan. Semakin tinggi profitabilitas maka semakin tinggi pula nilai perusahaan. Keempat, likuiditas berpengaruh terhadap nilai perusahaan. Informasi mengenai likuiditas perusahaan bisa digunakan untuk memprediksi nilai perusahaan. Semakin tinggi likuiditas akan menurunkan nilai perusahaan, sebaliknya semakin rendah likuiditas akan meningkatkan nilai perusahaan. Hal ini disebabkan oleh sudut pandang investor yang menginginkan agar aset yang dimiliki perusahaan dapat digunakan semaksimal mungkin dalam meningkatkan laba, ekspansi bisnis, atau peningkatan aktivitas operasional dari pada dibiarkan berpeluang menjadi dana menganggur. Terakhir, solvabilitas berpengaruh terhadap nilai perusahaan. Informasi mengenai solvabilitas bisa digunakan untuk memprediksi nilai perusahaan. Semakin tinggi solvabilitas maka semakin tinggi pula nilai perusahaan. Secara keseluruhan, penelitian ini berhasil membuktikan bahwa teori signaling masih relevan digunakan di konteks Indonesia. Selain itu, penelitian ini mengonfirmasi bahwa mentalitas akuntansi yang membebankan biaya pemasaran karena kesulitan mengukur manfaat ekonominya justru dipandang secara berbeda oleh investor. Pasar modal melihat beban pemasaran sebagai faktor penentu nilai perusahaan dan pertumbuhan di masa mendatang.

\section{Saran}

Bagi peneliti yang akan melakukan penelitian terkait faktor-faktor penentu nilai perusahaan, penelitian ini memberikan saran sebagai berikut. Pertama, variabel Aktivitas Pemasaran dalam penelitian ini mengukur besarnya nilai buku beban pemasaran. Dengan demikian, semakin besar nilai buku beban pemasaran maka semakin besar pula nilai perusahaan, namun demikian, besarnya jumlah investasi untuk aktivitas pemasaran tidak cukup menjelaskan efektifitas aktivitas pemasaran dalam meningkatkan nilai perusahaan. Investasi pemasaran yang kecil sekalipun apabila dilakukan efektif akan menghasilkan pen- 
jualan yang luar biasa dan akan berkontribusi besar meningkatkan nilai perusahaan, oleh karena itu, penilaian aktivitas pemasaran selain berfokus kepada besarnya nilai dari beban pemasaran itu sendiri juga berforkus pada efektifitas strategi pemasaran perusahaan. Kebijakan strategi pemasaran akan lebih menggambarkan kompetensi manajemen sesungguhnya pada saat ini dan prospek pertumbuhan. Kedua, variabel aset tidak berwujud dalam penelitian ini mengukur besarnya pengungkapan nilai buku aset tidak berwujud. Hal itu menyebabkan penelitian ini tidak memperoleh cukup data karena hanya sedikit perusahaan di sektor industri barang konsumsi yang mengungkapkan nilai aset tidak berwujud. Untuk penelitian selanjutnya, peneliti bisa memperluas cakupan populasi perusahaan yang juga memperoleh manfaat besar dari kepemilikan aset tidak berwujud. Ketiga, penelitian ini menyarankan agar penelitian pasar modal di masa mendatang juga mengombinasikan data akuntansi, sebagai pendekatan konvensional, dengan berbagai variabel alternatif yang bisa memprediksi kinerja masa depan perusahaan. Dengan demikian, hal ini akan memperkaya teori penilaian perusahaan.

\section{DAFTAR PUSTAKA}

Adnyana, I. G. dan I. B. Badjra. 2014. Pengaruh Likuiditas, Manajemen Aktiva, EPS, dan Ukuran Perusahaan Terhadap Kebijakan Dividen dan Nilai Perusahaan. E-Jurnal Manajemen Universitas Udayana 3(12): 3703-3724.

Allazy, M. R. 2013. Pengaruh Leverage, Profitabilitas, Likuiditas, Kebijakan Dividen, Ukuran Perusahaan dan Pertumbuhan Perusahaan Terhadap Nilai Perusahaan. Jurnal Ilmiah Universitas Bakrie 1(02): 2-3.

Ammann, M., D. Oesch, dan M. M. Schmid. 2011. Corporate Governance and Firm Value: International Evidence. Journal of Empirical Finance 18(1): 36-55.

Anjum, B., S. K. Dhanda, dan S. Nagra. 2012. Impact of Celebrity Endorsed
Advertisements on Consumers. Asia Pacific Journal of Marketing \& Management Review 1(2): 22-33.

Biddle, G. C. dan G. Hilary. 2006. Accounting Quality and Firm-Level Capital Investment. The Accounting Review 81(5): 963-982.

Chauvin, K. W. dan M. Hirschey. 1993. Advertising, R\&D Expenditures and The Market Value of The Firm. Financial Management 22(4): 128-140.

Chen, M.-C., S.-J. Cheng, dan Ogun Y. Hwang. 2005. An Empirical Investigation of The Relationship Between Intellectual Capital and Firms' Market Value and Financial Performance. Journal of Intellectual Capital 6(2): 159176.

Christensen, H. B. dan V. V. Nikolaev. 2013. Does Fair Value Accounting For NonFinancial Assets Pass The Market Test? Review of Accounting Studies 18(3): 734775.

Chung, K. H. dan S. W. Pruitt. 1994. A Simple Approximation Of Tobin's Q. Financial Management: 70-74.

Ciawi, A., dan S. E. Hatane. 2015. Pengaruh Marketing Activity Terhadap Return On Asset dan Market To Book Value Perusahaan Di Sektor Industri Keuangan Non-Bank. Business Accounting Review 3(1): 156-167.

Dechow, P. M. dan D. J. Skinner. 2000. Earnings Management: Reconciling The Views of Accounting Academics, Practitioners, and Regulators. Accounting Horizons 14(2): 235-250.

Edeling, A. dan M. Fischer. 2016. Marketing's Impact On Firm Value: Generalizations From A Meta-Analysis. Journal of Marketing Research 53(4): 515-534.

Eisfeldt, A. L. dan D. Papanikolaou. 2014. The Value and Ownership of Intangible Capital. The American Economic Review 104(5): 189-194.

Gardberg, N. A. dan C. J. Fombrun. 2006. Corporate Citizenship: Creating Intangible Assets Across Institutional 
Environments. Academy of Management Review 31(2): 329-346.

Gow, I. D., G. Ormazabal, dan D. J. Taylor. 2010. Correcting for Cross-Sectional and Time-Series Dependence in Accounting Research. The Accounting Review 85(2): 483-512.

Grewal, D., G. R. Iyer, W. A. Kamakura, A. Mehrotra, dan A. Sharma. 2009. Evaluation of Subsidiary Marketing Performance: Combining Process and Outcome Performance Metrics. Journal of the Academy of Marketing Science 37(2): 117-129.

Gurun, U. G. dan A. W. Butler. 2012. Don't Believe The Hype: Local Media Slant, Local Advertising, and Firm Value. The Journal of Finance 67(2): 561-598.

Hall, R. 1992. The Strategic Analysis of Intangible Resources. Strategic Management Journal 13(2): 135-144.

Hardiyanti, N. 2012. Analisis Pengaruh Insider Ownership, Leverage, Profitabilitas, Firm Size dan Dividen Payout Ratio Terhadap Nilai Perusahaan (Studi Pada Perusahaan Manufaktur Yang Terdaftar di BEI Tahun 2007-2010). Skripsi. Fakultas Ekonomika dan Bisnis Universitas Diponegoro. Semarang.

Hermuningsih, S. 2013. Pengaruh Profitabilitas, Growth Opportunity, Struktur Modal Terhadap Nilai Perusahaan Pada Perusahaan Publik Di Indonesia. Buletin Ekonomi Moneter dan Perbankan 16(2): 127-148.

Ikatan Akuntan Indonesia. 2016. Standar Akuntansi Keuangan Per Efektif 1 Januari 2017. Ikatan Akuntan Indonesia. Jakarta

Irawan, D. T., dan S. E. Hatane. 2015. Pengaruh Kegiatan Marketing Terhadap Profitabilitas dan Nilai Pasar Di Perusahaan Perbankan. Business Accounting Review 3(1): 112-122.

Jo, H., dan M. A. Harjoto. 2011. Corporate Governance and Firm Value: The Impact of Corporate Social Responsibility. Journal of Business Ethics 103(3): 351-383.
Kanagal, N. 2009. Role of Relationship Marketing In Competitive Marketing Strategy. Journal of Management and Marketing Research 2(Mei): 1-17.

Kementerian Perindustrian Indonesia. 2014. Manufaktur Ditopang Sektor Barang Konsumsi. http://www.kemenperin.go.id/ artikel/7014/Manufaktur-Ditopang-SektorBarang-Konsumsi. Diakses tanggal 2 Februari 2016.

Kim, Y. dan J. Joo. 2013. The Moderating Effect of Product Market Competition In The Relationship between Advertising Expenditures and Sales. Journal of Applied Business Research 29(4): 10611076.

Kotler, P. dan G. Armstrong. 2014. Principles of Marketing. 15th ed. Pearson Education. England

Liang, L. dan E. J. Riedl. 2013. The Effect of Fair Value Versus Historical Cost Reporting Model On Analyst Forecast Accuracy. The Accounting Review 89(3): 1151-1177.

Mahendra Dj, A., L. G. S. Artini, dan A. A. G. Suarjaya. 2012. Pengaruh Kinerja Keuangan Terhadap Nilai Perusahaan Pada Perusahaan Manufaktur Di Bursa Efek Indonesia. Jurnal Manajemen, Strategi Bisnis dan Kewirausahaan 6(2): 130-138.

Morgan, N. A. 2012. Marketing and Business Performance. Journal of the Academy of Marketing Science 40(1): 102-119.

Morris, R. D. 1987. Signalling, Agency Theory and Accounting Policy Choice. Accounting and Business Research 18(69): 47-56.

Nielsen. 2015. Belanja Iklan Naik 6\% di Kuartal Kedua 2015. http://www.nielsen. com/id/en/press-room/2015/Belanja-IklanNaik-6-persen-di-Kuartal-Kedua2015.html. Diakses tanggal 30 Desember 2015.

Nini, G., D. C. Smith, dan A. Sufi. 2012. Creditor Control Rights, Corporate Governance, and Firm Value. The Review of Financial Studies 25(6): 17131761. 
Nurhayati, M. 2013. Profitabilitas, Likuiditas dan Ukuran Perusahaan Pengaruhnya Terhadap Kebijakan Dividen dan Nilai Perusahaan Sektor Non Jasa. Jurnal Keuangan dan Bisnis 5(2): 144-153.

Ogunsiji, A. S. 2012. The Impact of Celebrity Endorsement On Strategic Brand Management. International Journal of Business and Social Science 3(6): 141-146.

Petersen, M. A. 2009. Estimating Standard Errors In Finance Panel Data Sets: Comparing Approaches. Review of Financial Studies 22(1): 435-480.

Png, I. P. 2017. Law and Innovation: Evidence From State Trade Secrets Laws. Review of Economics and Statistics 99(1): 167-179.

Putra, R. A. dan J. Herawati. 2013. Pengaruh Profitabilitas, Struktur Modal, dan Likuiditas Terhadap Nilai Perusahan (Studi Pada Perusahaan Asuransi Di Bursa Efek Indonesia Tahun 2010-2012). Jurnal Ilmiah Mahasiswa FEB 2(2): 1-18.

Rompas, G. P. 2013. Likuiditas Solvabilitas dan Rentabilitas Terhadap Nilai Perusahaan BUMN Yang Terdaftar Di Bursa Efek Indonesia. Jurnal Riset Ekonomi, Manajemen, Bisnis Dan Akuntansi 1(3): 252-262.

Ruan, W., G. Tian, dan S. Ma. 2011. Managerial Ownership, Capital Structure and Firm Value: Evidence From China's Civilian-Run Firms. Australasian Accounting Business \& Finance Journal 5(3): 73-92.

Sari, N. M. Y. D. P. dan M. Chabachib. 2013. Analisis Pengaruh Leverage, Efektivitas Aset dan Sales Terhadap Profitabilitas serta Dampaknya Terhadap Nilai Perusahaan (Studi Pada Perusahaan Di Sektor Industri Barang Konsumsi Yang Terdaftar Di Bursa Efek Indonesia Periode Tahun 2007-2011). Diponegoro Journal of Management 2(3): 188-200.

Serenia, S., dan S. E. Hatane. 2015. Pengaruh Kegiatan Marketing terhadap Profitabilitas dan Nilai Perusahaan Properti dan Real Estate di BEI. Business Accounting Review 3(1): 268-279.

Setijawan, I. 2011. Pengaruh Aset Tidak Berwujud Terhadap Nilai Perusahaan. Aset 13(2): 139-154.

Sidhu, B. K. dan J. H. Roberts. 2008. The Marketing Accounting Interface-Lessons and Limitations. Journal of Marketing Management 24(7-8): 669-686.

Soraya, L. dan M. Syafruddin. 2013. Pengaruh Nilai Aset Tidak Berwujud dan Penelitian dan Pengembangan Terhadap Nilai Pasar Perusahaan (Studi Empiris pada Perusahaan Manufaktur yang Terdaftar di Bursa Efek Indonesia Tahun 2009-2010). Diponegoro Journal of Accounting 2(2): 1-9.

Srinivasan, S. dan D. M. Hanssens. 2009. Marketing and Firm Value: Metrics, Methods, Findings, and Future Directions. Journal of Marketing Research 46(3): 293-312.

Srivastava, A. 2014. Why Have Measures of Earnings Quality Changed Over Time? Journal of Accounting and Economics 57(2): 196-217.

Teece, D. J. 1998. Capturing Value From Knowledge Assets: The New Economy, Markets For Know-How, and Intangible Assets. California Management Review 40(3): 55-79.

Trisnajuna, M. dan E. A. Sisdyani. 2015. Pengaruh Aset Tidak Berwujud dan Biaya Penelitian dan Pengembangan Terhadap Nilai Pasar dan Kinerja Keuangan Perusahaan. E-Jurnal Akuntansi 13(3): 888-915.

Vomberg, A. C. Homburg, dan T. Bornemann. 2015. Talented People and Strong Brands: The Contribution of Human Capital and Brand Equity to Firm Value. Strategic Management Journal 36(13): 2122-2131.

Wahyuni, T., E. Ernawati, dan W. R. Murhadi. 2013. Faktor-Faktor yang Mempengaruhi Nilai Perusahaan Di Sektor Property, Real Estate \& Building Construction yang Terdaftar Di BEI Periode 2008-2012. CALYPTRA: Jurnal 
Ilmiah Mahasiswa Universitas Surabaya 2(1): 1-18.

Widhiastuti, N. L. P. dan M. Y. Latrini. 2015. Pengaruh Return On Asset dan Intangible Asset terhadap Nilai Perusahaan dengan Corporate Social Responsibility Sebagai Variabel Pemoderasi. E-Jurnal Akuntansi 11(2): 370383.
Wijaya, I. B. N. P. dan N. K. Purnawati. 2014. Pengaruh Likuiditas Dan Kepemilikan Institusional Terhadap Nilai Perusahaan Dimoderasi Oleh Kebijakan Dividen. E-Jurnal Manajemen Universitas Udayana 3(12): 3768-3780. 